\title{
Life Cycle Cost of Self-Supply Water in Metro City
}

\author{
Ikhtiar Jauhari ${ }^{1}$, Tri Edhi Budhi Soesilo ${ }^{1}$, and Cindy $R$ Priadi $^{2, *}$ \\ ${ }^{1}$ School of Environmental Science, Universitas Indonesia, Jalan Salemba Raya No. 4 Kampus UI \\ Salemba, Jakarta Pusat, 10430, Indonesia. \\ ${ }^{2}$ Civil and Environmental Engineering Department, Faculty of Engineering, Universitas Indoensia, \\ Depok, 16424, Indonesia.
}

\begin{abstract}
Self-supply of drinking water is implemented in areas where the coverage of piped water services is inadequate, low incomes residents, and poor performance of piped water supply. The Life Cycle Cost (LCC) is a method of evaluating all costs incurred and is used to track the financing of the drinking water sector. This study analyses LCC of self-supply water in the Metro City, Indonesia. A field survey was conducted using a questionnaire in October 2020 for households in Metro City that captured information on costs incurred for household water use. It was observed that self-supply water uses in Metro City accounts for $92.86 .30 \%$ of all water supplies. The average recurrent expenditure is Rp.224,344/ year with mean of capital cost is Rp.275,273. Most expensive cost for self-supply is borehole. High cost of borehole due deeper groundwater source, borehole use more pump electricity and higher drilling cost. This funding for selfsupply water is carried out independently by the households. These results highlighted the importance of self-financing for the water supply sector. Increased reliability and safety of self-supply require a better awareness of the costs and benefits of developing water sources. Furthermore, selfsupply water requires better governance to achieve safe water access.
\end{abstract}

\section{Introduction}

Universal access to safe drinking water is one of the 17 objectives of the Sustainable Development Goals (SDGs). To realize a liveable and sustainable settlement in Indonesia, the Rencana Pembangunan Jangka Menengah Nasional (RPJMN) 2020-2024 set a target of $0 \%$ urban slums, $90 \%$ access to sanitation, and $100 \%$ safe access to drinking water. Therefore, besides access coverage, safe access to drinking water in quality and quantity are also targeted to reach $15 \%$ [1]. Water consumption in Indonesia is $57 \%$ sourced from groundwater, and $35 \%$ is dug well. This shows the importance of managing the safety of drinking water access for the community.

\footnotetext{
*Corresponding author: cpriadi@ui.ac.id
} 
Access to adequate drinking water in Indonesia in 2019 reached $87.75 \%$. This access consists of $20.14 \%$ piping and $67.61 \%$ self-supply [2]. Based on the provincial data, $87.75 \%$ of provinces have not achieved decent drinking water coverage, such as Lampung, Papua, Bengkulu, Bangka Belitung, and South Kalimantan. Furthermore, only $48.94 \%$ of Lampung Province has safe access to drinking water [1]. One of the cities with the lowest access is Metro City, Lampung. Unit Pelaksana Teknis Penyediaan Air Minum (UPTPAM) Metro Lampung City has a service coverage of only $5.05 \%$, namely 2,134 customers from a total of 42,298 Households [3].

Efforts are required to achieve $100 \%$ access to safe drinking water in accordance with the target of RPJMN 2020-2024 with the current national service coverage condition of $87.75 \%$. Based on the allocation of funds by the government, the trend of increasing the average service coverage of the last 5 years $(2013-2018)$ is $1.43 \%$ [4], while the gap to reach $100 \%$ access to drinking water within the next 4 years is $12.25 \%$. The fulfillment of the portion of funding outside the State Budget was the Regional Budget (APBD), Special Allocation Fund (DAK), Government and Business Entity Cooperation Program (PPP), and Business to Business Scheme. Seeing the constraints and challenges of drinking water supply, alternative efforts are necessary to improve access to drinking water. One of the financing sources that has not been noticed by the government is household investment for drinking water. This investment is the provision of self-supply drinking water. This approach can help to improve coverage in areas where water from piping is not feasible, and helps to meet the costs of developing viable access to drinking water [5].

Self-supply drinking water provision is large enough to affect the scope of access to drinking water. The people of Metro City choose to provide their drinking water by selfsupply water services using shallow wells or boreholes, often equipped with electric pumps. Furthermore, self-supply helps to meet the scope of services provided by the public piping network. The preference of the people of Lampung city in choosing self-supply is due to the cost and unavailability of public drinking water services [6]. Despite its potential, the provision of drinking water independently is often not formally recognized as a model of providing services in government policy.

The Global Analysis and Assessment of Sanitation and Drinking-Water (GLAAS) reports that an estimated $66 \%$ of annual Water, Sanitation and Hygiene (WASH) financing comes from household contributions [7]. Household contribution refers to the payment of drinking water tariffs and household investment in self-supply provision. The phenomenon of selfsupply of drinking water in urban and suburban areas has begun to be widely recognized. Furthermore, users invest their own resources to build self-supply drinking water services in response to unreliable public piped water network [8], [9].

The UN-Water/WHO encourages countries to adopt methodologies to track financing to the WASH sector. The main objective is to complement and add value to existing drinking water supply programs and projects by facilitating synergy and joint efforts to maximize coordinated action and coherence throughout the system [7]. One of the method that used to track financing in water sector is Life Cycle Cost. The Life Cycle Cost (LCC) is an economic method for calculating all costs that occur, starting from the stage of construction, operation, and maintenance where it is in an important consideration to make decisions [10]. In 2010-2011 study conducted in India, Burkina Faso, Ghana and Mozambique resulting methodology of life-cycle aprroach to analyses all component cost 
of water services [11]. This method also be interpreted as cost to build and maintain the sustainability of a water system.

Data comparison between LCC paid for piping drinking water and Life Cycle Cost for selfsupply drinking water in seven countries showed that self-supply has a total expenditure of 3 times compared to piping drinking water in Bangladesh (2015), 11 times in Ghana (2014), and 56 times in Brazil (2014) [12]. In addition to these 3 countries, research on life cycle costs was also conducted in India, Burkina Faso, and Mozambique. The value of the life cycle cost issued was US\$ 17-21, meanwhile the life cycle cost of piping is US\$ 30-130 within water that meets service standards [11]. The Life Cycle Cost in Indonesia has not been performed for drinking water. Therefore, it will be useful to track financing to be the basis for formulate strategies to meet the costs of drinking water.

\section{Material and methods}

\subsection{Research framework}

This study was conducted in Metro City in October 2020 for 4 weeks. Five sub districts were selected: Ganjarasri, Hadimulyo Barat, Karangrejo, Iringmulyo and Rejomulyo. The sub-districts were selected because people in that area are highly depend on groundwater. Furthermore, pre-studies of the five districts observed slum areas which showed high levels of poverty. The households in Metro City also cannot utilize pipe water due to the limitation of PDAM coverage area.

\subsection{Data collection}

This study uses data from households survey to answer research questions. The data was collected from 315 households. The household answered questionnaires contains several questions about the cost incurred by households in providing drinking water. The data then used in analysis of life cycle cost. The methodology and cost component of life cycle cost in this research are based on life-cycle cost approach research by Burr and Foncesca (2013) which identify and analyses all the essential cost [11]. The method is used and modified after pre-survey to Metro City. The purpose of the modification is to simplify the question and eliminated components that is not available in Metro City. The components summarised in Table 1. 
Table 1. Life-cycle Cost Component

\begin{tabular}{|c|c|c|c|}
\hline \multicolumn{2}{|c|}{ Cost Component } & \multirow{2}{*}{$\begin{array}{l}\text { Description } \\
\text { Cost of providing } \\
\text { services, Capital } \\
\text { investment for } \\
\text { construction or } \\
\text { purchasing fixed assets } \\
\text { and software cost such as } \\
\text { permit of groundwater } \\
\text { use }\end{array}$} & \multirow{2}{*}{$\begin{array}{l}\text { Data } \\
\text { 1. Initial pump cost } \\
\text { 2. Construction cost of } \\
\text { Groundwater } \\
\text { 3. Pipe connection cost } \\
\text { 4. Groundwater permit cost }\end{array}$} \\
\hline $\begin{array}{l}\text { Capital } \\
\text { expenditure }\end{array}$ & $\begin{array}{l}\text { Capital } \\
\text { Expenditure }\end{array}$ & & \\
\hline \multirow[t]{2}{*}{$\begin{array}{l}\text { Recurrent } \\
\text { Expenditure }\end{array}$} & $\begin{array}{l}\text { Operational } \\
\text { Expenditure }\end{array}$ & $\begin{array}{l}\text { Operating expenditure of } \\
\text { water source. }\end{array}$ & $\begin{array}{l}\text { 1. Pump electricity, calculated } \\
\text { from pump operation times } \\
\text { (a), Pump wattage (b), } \\
\text { electricity prices per- } \\
\text { kilowatt hour (c) }\end{array}$ \\
\hline & $\begin{array}{l}\text { Capital } \\
\text { Maintenance } \\
\text { Cost }\end{array}$ & $\begin{array}{l}\text { Maintenance cost consist } \\
\text { of repairing cost of the } \\
\text { assets and renewal of the } \\
\text { assets }\end{array}$ & $\begin{array}{l}\text { 1. Cost of pump being repaired } \\
\text { 2. Cost of pump replacement } \\
\text { 3. Cost of well deepened }\end{array}$ \\
\hline
\end{tabular}

\subsection{Data analysis}

Data was categorized under two general component; capital expenditure that occur when providing a service where there was none, and operational cost that occur annually. The life cycle analysis will be provided in in 2 general expenditure. Capital expenditure is summation of initial pump cost (1), construction cost of groundwater (2), and pipe connection cost (3). Operational cost is annual total cost of electricity and maintenance cost in one year period.

Capital investment are calculated from the current prices of the assents. Electricity cost for pump calculated from pump operation times (a), Pump wattage (b), electricity prices perkilowatt hour (c) for one year period. Maintenance cost such as repairing the pump, pump replacement, and deepening the well not always appear every year. For this analysis, maintenance expenditure has been annualised by dividing by the age of system. The mean of age of system obtained from pre-survey was 10 years.

\section{Result and discussion}

\subsection{Metro City water source}

Self-supply provision by households is widely used in Metro City to fulfil drinking water needs. This is observed by the use of borehole and dug well by $20.07 \%$ and $65.65 \%$ compared to other supplies, as shown in Table 1. Users of piping services out of 315 respondents were 5 households or about $1.70 \%$. In addition to these three categories, households obtain drinking water from other types of sources. The self-supply water provision was performed by households at personal costs ranging from digging / drilling to 
the purchasing of pumps. The expenditure calculation was divided by the type of water supply into borehole (private, neighbour, and public), dug wells (private, neighbour, and public), refilled water, and bottled water.

Table 2. Water Source of Metro City

\begin{tabular}{|l|c|c|}
\hline Water Source & Amount of Data & Percentage \\
\hline Neighbour's borehole & 8 & $2.72 \%$ \\
\hline Neighbour's dug well & 8 & $2.72 \%$ \\
\hline Piped to premises & 5 & $1.70 \%$ \\
\hline Private borehole & 59 & $20.07 \%$ \\
\hline Private dug well & 193 & $65.65 \%$ \\
\hline Public borehole & 21 & $7.14 \%$ \\
\hline
\end{tabular}

In Metro City, self-supply drinking water with private borehole and dug wells is common. Households in Metro City have borehole or dug wells built on the land of the household. The wells are used by households which occupy the land for daily needs. A small part of the well built on the land of the house is used in conjunction with up to 5 houses.

Self-supply of drinking water supply in Metro City has the largest percentage of use, but this self-supply model has not been calculated as the achievement of drinking water supply coverage. In addition, the reliability of self-supply model cannot be ascertained. This can be seen from the analysis of self-supply sources that rely entirely on groundwater. Provision of self-help in metro cities that use a lot of groundwater is the same as in research in Africa which also uses groundwater as a source [13].

Water is lifted from ground by household with two method; motorized pump, and rope and bucket. Motorized pump is used in every borehole and Neighbour's borehole. Household also use motorized pump in dug well. Household use motorized pump is used to reduce the amount of time to lift the water. 150 of 193 household with private dug well used motorized pump and 1 of 8 household with neighbour's dug well used motorized pump. The other household used rope un bucket for lifting the water.

In areas such as Karangrejo which has services with piping water networks or PDAM, based on the respondent survey, more than $90 \%$ did not use piped water network for their water and instead use boreholes and dug wells, or public borehole. Their reasons for not using piping water supplies vary, but include issues directly related to prices that are not affordable to the community. In addition, the community is also aware that PDAM water is not safe to drink. Problems exist in the community related to public piping services were also highlighted, such as the social status of users, perceptions of water quality (not actual) and the availability of alternative sources or private water providers [10].

The provision of self-supply drinking water by households is mostly used solely, as there is often no alternative source. Only two respondents confirmed that the source had ever dried up. Respondents who experienced drought adopted refill water as an alternative source. 


\subsection{Metro City Life Cycle Cost}

Data from the 315 households where the survey was conducted showed that household spending on self-supply sources varied widely. This study grouped life cycle costs based on the type of water source used. The costs incurred independently come from the household without assistance from external parties. Household costs for borehole and private wells occur because public provision that is not affordable for community and service coverage has not reached the area. Furthermore, on all villages, more than $90 \%$ of respondents have a private water source.

The calculation of capital expenditure was carried out using capital expenditure hardware data, as that of the software is not available in Metro City. The capital expenditure software component arguably has a value of 0 because components such as the cost for licensing in groundwater extraction do not exist. Therefore, this was at variance with research [11] where the cost of capital expenditure software in the country was permitted for groundwater use. In analysis of operational expenditure we found that household using private dug well has expenses close to the cost of operational in private borehole because of motorized pump also used in private dug well. The summary of life cycle cost shown in Table 3.

Table 3. Mean Life-Cycle Cost of Metro city

\begin{tabular}{|c|r|r|r|r|}
\hline & $\begin{array}{c}\text { Capital } \\
\text { expenditure }\end{array}$ & \multicolumn{2}{|c|}{ Recurrent Expenditure } & \\
\hline Water Source & $\begin{array}{c}\text { Capital } \\
\text { expenditure } \\
\text { (Rupiah) }\end{array}$ & $\begin{array}{c}\text { Operational } \\
\text { expenditure } \\
\text { (Rupiah/year) }\end{array}$ & $\begin{array}{c}\text { Capital } \\
\text { maintenance } \\
\text { expenditure } \\
\text { (Rupiah/year) }\end{array}$ & $\mathrm{n}$ \\
\hline Private borehole & 920,532 & 136,041 & 135,092 & 59 \\
\hline Private dug well & 241,668 & 102,039 & 82,803 & 193 \\
\hline Public borehole & 106,666 & 529,232 & 0 & 21 \\
\hline Neighbor's borehole & 81,250 & 256,252 & 0 & 8 \\
\hline Neighbor's Dug well & 26,250 & data not available & data not available & 8 \\
\hline Piped to premises & 140,000 & $1,342,754$ & 0 & 5 \\
\hline
\end{tabular}

Table 3 shows the highest mean of capital expenditure is private borehole with Rp.920,532.87. Highest capital expenditures were obtained for a total of 59 boreholes with machine pumps. As shown in Table 3, the average capital expenditure per drill hole in all regions is $\mathrm{Rp}$ 920.533. The average depth of drill holes in all regions was observed to be 30 $\mathrm{m}$. Therefore, the expenditure of boreholes on average per meter amounted to Rp30.684. Private dug wells are the third source with the largest capital cost. Similar to the borehole, the capital expenditure of the well is obtained from the cost of excavation, purchase of pumps, and the manufacture of well walls. Capital expenditure is the largest component of the dug well's LCC but the amount is less than the capital expenditure of boreholes. This is because some households use pulleys and buckets to fetch water, therefore there is no cost of purchasing pumps and digging wells is cheaper. 
Highest operational expenditure for self-supply is public borehole with Rp.529,232.57/year. Piped to premises is the highest operational expenditure for all system with Rp.1,342,754.03/year. The calculation of operational expenditure components is quite large because people within public borehole and piping water sources pay monthly costs for water usage. The life cycle costs of piping obtained from 5 households signify a possibility of a greater total average expenditure. The expenditure of capital maintenance only occur in private borehole and private dug well Household with neighbour's and public water source usually did not pay for capital maintenance, the expenses is paid by the owner of water source infrastructure. Data collection in this study had a limitation that the value of expenditure obtained in the analysis of life cycle cost was based on the respondent's memory. Therefore, a mismatch with the real condition may occur.

Expenditures for borehole are also quite varied due to differences in depth and type of pumps used in water sources in each sub-district. Furthermore, drill with a deeper depth makes capital and operational costs higher, as in Karangrejo Subdistrict. Life cycle cost obtained from respondent's answers based on sub-districts showed that the private borehole had the highest capital expenditure in every sub-districts except Rejomulyo. Rejomulyo capital expenditure for private borehole has lowest groundwater construction cost and used shallow pump. The lowest construction cost of groundwater also shown in private dug well for Rejomulyo. The life cycle cost of Metro city water source categorized by sub-district is shown in Table 4.

Table 4. Life-cycle cost categorized by Sub-district

\begin{tabular}{|c|c|c|c|c|c|c|}
\hline $\begin{array}{l}\text { Water } \\
\text { Source }\end{array}$ & Component & Ganjarasri & $\begin{array}{l}\text { Hadimulyo } \\
\text { Barat }\end{array}$ & Iringmulyo & Karangrejo & Rejomulyo \\
\hline \multirow[t]{3}{*}{$\begin{array}{c}\text { Private } \\
\text { borehole }\end{array}$} & $\begin{array}{l}\text { Capital } \\
\text { expenditure } \\
\text { (Rupiah) }\end{array}$ & $1,069,636$ & 814,034 & $1,336,667$ & $2,280,000$ & 300,020 \\
\hline & $\begin{array}{c}\text { Recurrent } \\
\text { expenditure } \\
\text { (Rupiah/year) }\end{array}$ & 502,824 & 237,021 & 19,865 & 198,285 & 10,835 \\
\hline & $\mathrm{N}$ & 11 & 41 & 3 & 2 & 2 \\
\hline \multirow[t]{3}{*}{$\begin{array}{l}\text { Private } \\
\text { dug well }\end{array}$} & $\begin{array}{l}\text { Capital } \\
\text { expenditure } \\
\text { (Rupiah) }\end{array}$ & 446,686 & 202,156 & 232,434 & 296,713 & 79,760 \\
\hline & $\begin{array}{c}\text { Recurrent } \\
\text { expenditure } \\
\text { (Rupiah/year) }\end{array}$ & 324,111 & 185,890 & 161,214 & 117,773 & 86,586 \\
\hline & $\mathrm{N}$ & 25 & 32 & 65 & 39 & 32 \\
\hline \multirow[t]{3}{*}{$\begin{array}{c}\text { Public } \\
\text { borehole }\end{array}$} & $\begin{array}{l}\text { Capital } \\
\text { expenditure } \\
\text { (Rupiah) }\end{array}$ & 42,857 & $\begin{array}{l}\text { Data not } \\
\text { available }\end{array}$ & $\begin{array}{l}\text { Data not } \\
\text { available }\end{array}$ & 158,182 & 848,126 \\
\hline & $\begin{array}{c}\text { Recurrent } \\
\text { expenditure } \\
\text { (Rupiah/year) }\end{array}$ & 5,572 & $\begin{array}{l}\text { Data not } \\
\text { available }\end{array}$ & $\begin{array}{l}\text { Data not } \\
\text { available }\end{array}$ & 34,697 & 100,000 \\
\hline & $\mathrm{N}$ & 7 & 0 & 1 & 11 & 2 \\
\hline \multirow[t]{2}{*}{$\begin{array}{l}\text { Neighbor's } \\
\text { borehole }\end{array}$} & $\begin{array}{l}\text { Capital } \\
\text { expenditure } \\
\text { (Rupiah) }\end{array}$ & $\begin{array}{l}\text { Data not } \\
\text { available }\end{array}$ & 0 & $\begin{array}{l}\text { Data not } \\
\text { available }\end{array}$ & 325,000 & $\begin{array}{l}\text { Data not } \\
\text { available }\end{array}$ \\
\hline & $\begin{array}{l}\text { Recurrent } \\
\text { expenditure }\end{array}$ & $\begin{array}{l}\text { Data not } \\
\text { available }\end{array}$ & 2,709 & $\begin{array}{l}\text { Data not } \\
\text { available }\end{array}$ & 248,126 & $\begin{array}{c}\text { Data not } \\
\text { available }\end{array}$ \\
\hline
\end{tabular}




\begin{tabular}{|c|c|c|c|c|c|c|}
\hline $\begin{array}{c}\text { Water } \\
\text { Source }\end{array}$ & Component & Ganjarasri & \multicolumn{2}{|c|}{ Hadimulyo } \\
Barat & \multicolumn{1}{|c|}{ Iringmulyo } & Karangrejo & Rejomulyo \\
\hline & (Rupiah/year) & & & & & \\
\hline & N & 0 & 6 & 0 & 2 & 0 \\
\hline $\begin{array}{c}\text { Neighbor's } \\
\text { dug well }\end{array}$ & $\begin{array}{c}\text { Capital } \\
\text { expenditure } \\
\text { (Rupiah) }\end{array}$ & $\begin{array}{c}\text { Data not } \\
\text { available }\end{array}$ & $\begin{array}{c}\text { Data not } \\
\text { available }\end{array}$ & $\begin{array}{c}\text { Data not } \\
\text { available }\end{array}$ & 15,000 & 60,000 \\
\hline & $\begin{array}{c}\text { Recurrent } \\
\text { expenditure } \\
\text { (Rupiah/year) }\end{array}$ & $\begin{array}{c}\text { Data not } \\
\text { available }\end{array}$ & $\begin{array}{c}\text { Data not } \\
\text { available }\end{array}$ & $\begin{array}{c}\text { Data not } \\
\text { available }\end{array}$ & 0 & 0 \\
\hline & N & 0 & 0 & 0 & 6 & 2 \\
\hline $\begin{array}{c}\text { Piped to } \\
\text { premises }\end{array}$ & $\begin{array}{c}\text { Capital } \\
\text { expenditure } \\
\text { (Rupiah) }\end{array}$ & $\begin{array}{c}\text { Data not } \\
\text { available }\end{array}$ & $\begin{array}{c}\text { Data not } \\
\text { available }\end{array}$ & 140,000 & $\begin{array}{c}\text { Data not } \\
\text { available }\end{array}$ & $\begin{array}{c}\text { Data not } \\
\text { available }\end{array}$ \\
\hline & $\begin{array}{c}\text { Recurrent } \\
\text { expenditure } \\
\text { (Rupiah/year) }\end{array}$ & $\begin{array}{c}\text { Data not } \\
\text { available }\end{array}$ & $\begin{array}{c}\text { Data not } \\
\text { available }\end{array}$ & $1,074,203$ & $\begin{array}{c}\text { Data not } \\
\text { available }\end{array}$ & $\begin{array}{c}\text { Data not } \\
\text { available }\end{array}$ \\
\hline & N & 0 & 0 & 5 & 0 & 0 \\
\hline
\end{tabular}

The recurrent expenditure on dug well ranges from Rp86.586-Rp.324.111/year, highest expenditure is in Ganjarasri. The annual expenditure of dug well has a slight difference in each sub-district because of differences in the cost of constructing wells and used of motorized pump in some household. Used of motorized pump by household in Ganjarasri is $80 \%$, this causes recurrent expenditure in Ganjarasri costly. Rejomulyo's household use rope and bucket for lifting water this condition show the low-priced recurrent expenditure.

Public borehole available in Ganjarasri, Karangrejo, and Rejomulyo. The capital cost of public borehole consist of installation of pump, pipe, and tap for household. Location of the source of public borehole determine capital cost, as seen in Rejomulyo, household need to install pump and longer pipe. This costly component also has impact to annual electricity cost. Recurrent cost in public borehole also influenced by monthly cost of water used in each household. Not available data in Table 4 caused by some district did not use selection of water type.

Piped to premises or public piped water only used by household in Iringmulyo. The annual expenditure of Piped water is the highest among all type of water source. Metro City has the ratio for recurrent cost of self-supply water and piped to premises is 1:6. For comparison from WHO (2017) studies, Bangladesh has 3:1 ratio, 11:1 for Ghana, and 1:56 for Brazil [7]. The piped water price for Bangladesh and Ghana is higher than annual cost of self-supply. Metro City has higher cost of piped water but Brazil has the lowest ratio because of pricey piped water.

\section{Conclusion}

The provision of drinking water in Metro Lampung City is dominated by the use of ground water, with $65.65 \%$ of the people has private dug wells, $20.07 \%$ have private dug wells, $7.14 \%$ have public boreholes, $2.72 \%$ of neighbour's drilled and dug wells, and $1.70 \%$ have a piping network to meet their daily needs. Household in Metro City rely on groundwater for their water needs. This is shown by used of borehole and dug well as type of water source. 
The highest capital and recurrent expenditure is for households that use boreholes because there are pumps that require considerable electricity, more expensive drilling cost, and cost of deep well pump. Furthermore, there are unexpected costs, such as when there are problems with the pump. The use of public boreholes can be an inexpensive alternative for every subdistrict except Rejomulyo, because capital expenditures and operations can be carried out independently. However, community institutions are required in order to maintain the infrastructure that has been built. So far, maintenance of well infrastructure, both private and public, on average, is not carried out routinely, and costs are incurred when a component is damaged.

This research shows that the average financing made by the household for self-supply is Rp.224,344/year. The Financing represents the costs incurred to meet $83 \%$ of the community's drinking water supply of the total respondents. Metro City Water Supply UPT service data reports that $95 \%$ of the total respondents are not served by piping [3] and in this study, self-help provision covers $83 \%$ of the total respondents drinking water supply.

Ratio of recurrent cost of self-supply and piped water shows household in Metro City pay water less than water tariff from piped water. This ratio describe government need financing strategies to increase drinking water coverage by using public pipe. The alternative for increasing safely manage drinking water is to improve self-supply water. increased reliability and safety of self-supply require a better awareness of the costs and benefits of developing water sources. Local governments can establish consultancy services and (micro) financial support, assistance in identifying suitable drinking water supply options, and promote applicable and more reliable technologies such as protected wells, bore wells with safe construction and piping. Meanwhile, government as the stakeholder need to Identify approaches in sector appraisal and investment plans to enable better targeting of public funds to help self-supply and. This requires adjusting the roles of stakeholders, and financing mechanisms.

This research received funding from Water for Woman, with the support of Australian Government Department of Foreign Affairs and Trade (number WRA1: 1004) and for publication paper was funded by PTUPT from Indonesia Ministry of Research and Technology with contract number NKB277/UN2.RST/HKP.05.00/2021 and also collaborative PPKI program from the Indonesia World Class University Research Scheme. We thank to Tim Foster and Prof. Juliet Willetts from ISF-UTS for imparting her knowledge and expertise in this study. We also thank to Franziska Genter from ISFUTS for her guidance and help for completing research.

\section{References}

1. Kementerian PPN/Bappenas. Akses Air Minum Nasional 2018. (2018).

2. Kementerian PPN/Bappenas. Dukung Program Advokasi Terhadap Pimpinan Daerah Untuk Percepat Capaian Air Bersih dan Sanitasi Layak. 24 Sepetember 1 (2019). Available at: https://www.bappenas.go.id/id/berita-dan-siaran-pers/menteribambang-dukung-program-advokasi-terhadap-pimpinan-daerah-untuk-percepatcapaian-air-bersih-dan-sanitasi-layak/. (Accessed: 26th July 2020)

3. BPS Kota Metro. Kota Metro Dalam Angka. (2019).

4. BPS. Persentase Rumah Tangga menurut Provinsi dan Sumber Air Minum Layak, 1993-2019. (2020).

5. S. Smits and S. Sutton. Self supply: the case for leveraging greater household investment in water supply extend first to the most accessible. (2015). 
6. O. Agustin. Analisis Kualitas Pelayanan Penyediaan Air Bersih Di UPT Air Minum Kota Metro. (2015).

7. WHO (World Health Organization). Safely managed drinking water. World Heal. Organ. (2017). doi:ISBN 9789241565424

8. J. Grönwall. Env. Earth Sc 75, 1-10 (2016).

9. Y. Chakava, R. Franceys, and A. Parker. Habitat Int. 43, 108-116 (2014).

10. S. Godfrey and G. Hailemichael. J. Water Sanit. Hyg. Dev. 7, 601-610 (2017).

11. P. Burr and C. Fonseca. WASHCost Glob. Work. Pap. 94 (2013).

12. WHO (World Health Organization). Financing Universal Water, Sanitation and Hygiene Under The Sustainable Development Goals. Un-Water Global Analysis and Assessment of Sanitation And Drinking-Water (GLAAS) 2017 report. (2017).

13. J. Wegmann and O. Mußhoff. Ecol. Econ. 166, 106432 (2019). 